トピックス

\title{
単一分子蛍光分光で見える光合成アンテナ系の 摇らぐエネルギ一移動経路
}

柴田 穣 東北大学大学院理学研究科

\section{1.|はじめに}

地上の太陽光強度は, クロロフィルのような強い吸 収バンドを持つ分子でも 1 秒に数回励起される程度で しかない，植物の光合成は，葉緑体内のチラコイド膜 に埋め込まれた光化学系 II（photosystem II: PSII）から 光化学系 I（photosystem I: PSI）への電子移動で駆動さ れるが，このような低濃度の光子エネルギーを光合成 の電荷分離反応を担う反応中心へと濃縮する光合成了 ンテナ系は, 高効率な光合成の営みに必須の分子装置 である．天然の光合成アンテナ系は，必ずしも光捕集 効率を最適化するように進化してきたのではないよう にも見え，その設計思想は明らかではない。本稿で は，単一分子分光法から見えてきた光合成アンテナ系 を形作る設計思想について議論したい.

フェルスター公式は，ドナー分子の励起エネルギー がアクセプター分子よりも若干高くなることで，高い 方から低い方へのエネルギーの流れが生じることを示 している，つまり，高効率に励起エネルギーを反応中 心へと集めるには，反応中心に向かって励起エネル ギーが徐々に下がっていく漏斗のような空間的バイア スを実現することが望ましい，光合成タンパク質は， 多数結合するクロロフィル分子それぞれの結合部位近 傍に適切な電荷を持つアミノ酸残基を配置すること で，励起エネルギーを調節している．調節された励起 エネルギーは，その場所でのエネルギーという意味で サイトエネルギーと呼ばれる。 サイトエネルギーの調 節により，光合成タンパク質は漏斗状のエネルギー地 形を実現していると考えられてきた。しかし，光合成 タンパク質に結合する色素分子それぞれのサイトエネ ルギーを精度高く求めることは現在でも困難で，漏斗 状エネルギー地形はあくまで概念上のものであり，実 際どうなっているかはよく分かっていないささらに， ポリペプチド鎖でできたタンパク質ではある程度のコ ンフォメーション摇らぎがあり，タンパク質に非共有
結合で固定されたクロロフィル分子の環境も摇らぎ, サイトエネルギーも摇らぐ.

図 1 は, PSII に結合する 37 個のクロロフィル分子 の理論的に予想されたサイトエネルギー ${ }^{1)}$ を反応中心 からの距離に対してプロットしたものである。図1か ら，PSII アンテナ系においては漏斗状といらょりもか なり平らなエネルギー地形となって招り，反応中心か ら離れた位置に低いサイトエネルギーを持つ色素が配 置されていることが分かる，図１には，理論的に予 想されたサイトエネルギーの摇らぎ幅をエラーバーで 示したが，摇らぎ幅がエネルギー移動の経路に無視で きない効果を持つであろらことも分かる．単一分子分 光では，間接的ではあるがそのような摇らぎを実験的 に検出することができる。こうした実験から，漏斗状 のエネルギー地形実現とは違う戦略を光合成系が採用 している可能性が見えてきた.

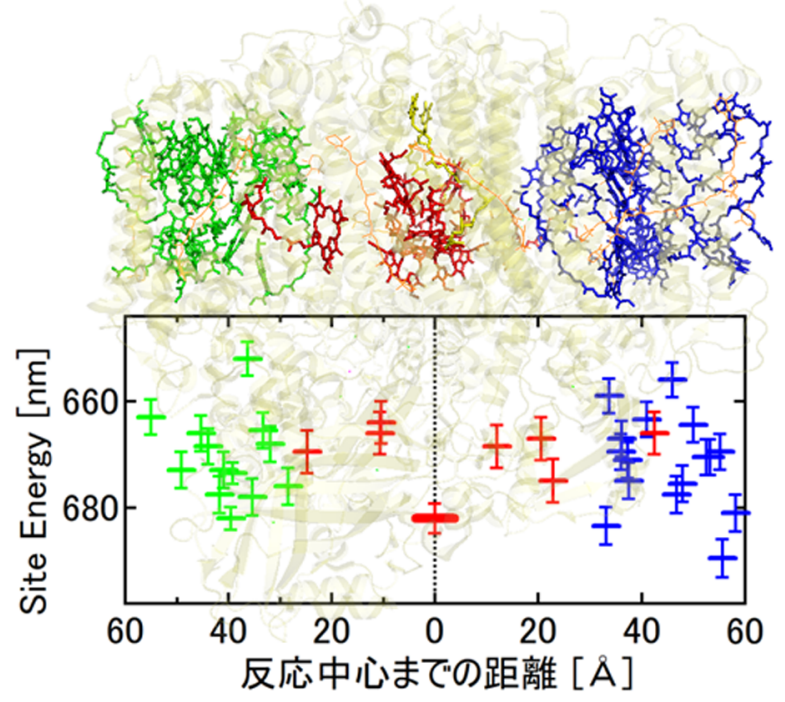

図 1

PSII に結合する 37 個の色素分子のサイトエネルギーの予想值を, 反応中心クロロフィルへの距離に対してプロット．上はPSII の結 晶構造.

Fluctuating Energy-Transfer Pathway of Photosynthetic Antenna Systems Observed by Single-Molecule Fluorescence Spectroscopy Yutaka SHIBATA

Graduate School of Science, Tohoku University 


\section{2. 単一光化学系।の蛍光スペクトル摇らぎ}

これまで，いくつかの光合成アンテナタンパク質で 単一分子分光の報告があり, 一つのタンパク質からの 蛍光スペクトルや強度 ${ }^{2)}, 3$, 蛍光寿命 $\left.{ }^{4}\right)$ が摇らいでい ることが報告されている，我々は，光エネルギー捕集 を担らアンテナ系と光誘起電子移動反応を担ら反応中 心が一体となった PSI について単一分子分光研究を行 らため，低温で高い開口数 0.9 を実現する共焦点顕微 鏡の開発を行ってきた ${ }^{5)}$. PSI は，室温では高効率な 光誘起電荷分離反応を起こすため蛍光収率は非常に低 く, 単一PSI からの蛍光を検出するには，蛍光収率が 高くなる低温での測定が必要となる.

PSI で最初の電荷分離を担う反応中心は, タンパク 質のほぼ中央にあるクロロフィル二量体とされ，その 吸収波長から P700 と呼ばれる。P700から放出された 電子は，キノンなどの電子受容体をいくつか経て還元 物質の生成に使われる。一つの PSI に結合する約 100 分子のクロロフィルの大半はアンテナ色素として働 き，それらのらちの数個が P700よりも低いサイトエ ネルギーを持つことが知られ， red Chl と呼ばれる. red Chl から P700へのエネルギー移動には，その波長 差に相当する $50 \mathrm{meV}$ ほどの熱エネルギーの入力が必 要となり， $100 \mathrm{~K}$ 以下の低温では起こらなくなる。そ のため, 低温では一旦励起エネルギーが red Chlへ到 達すると，高い確率で蛍光として放出される。低温で PSI の蛍光収率が高くなるのはこのためである.

図 2 は, $100 \mathrm{~K}$ で観測された単一PSI 三量体の蛍光 スペクトルを数分間追跡したものである ${ }^{6)}$. 220 秒の 観測の間，激しく蛍光強度が明滅するのが見られた。 この分子の場合，蛍光スペクトルのピーク位置の摇ら ぎが強度の明滅と同時に起こっている，蛍光強度が高 い時間帯と低い時間帯で平均した蛍光スペクトルをそ れぞれ青と緑で示しているが，ピーク位置のシフトが 明瞭に観測されている。測定した他の分子では，スぺ クトルのピーク位置は一定で強度が明滅する場合も多 くあった. このよらな蛍光の明滅は, 全てのPSI 分子 で起こる訳ではないが，明滅する分子では何度測定し ても明滅する，といら再現性があった。図 2 で示し た分子では蛍光の強度に依存してピーク位置が変化す るのは，PSI 三量体のモノマーそれぞれに異なる蛍光 波長の red Chl があり，それぞれが明滅することに対 応する。

あらかじめ P700を酸化すると，電荷分離反応が起 こらず電子受容体であるキノンは中性状態に保たれ る。一方，P700を中性にしたサンプルでは単一分子

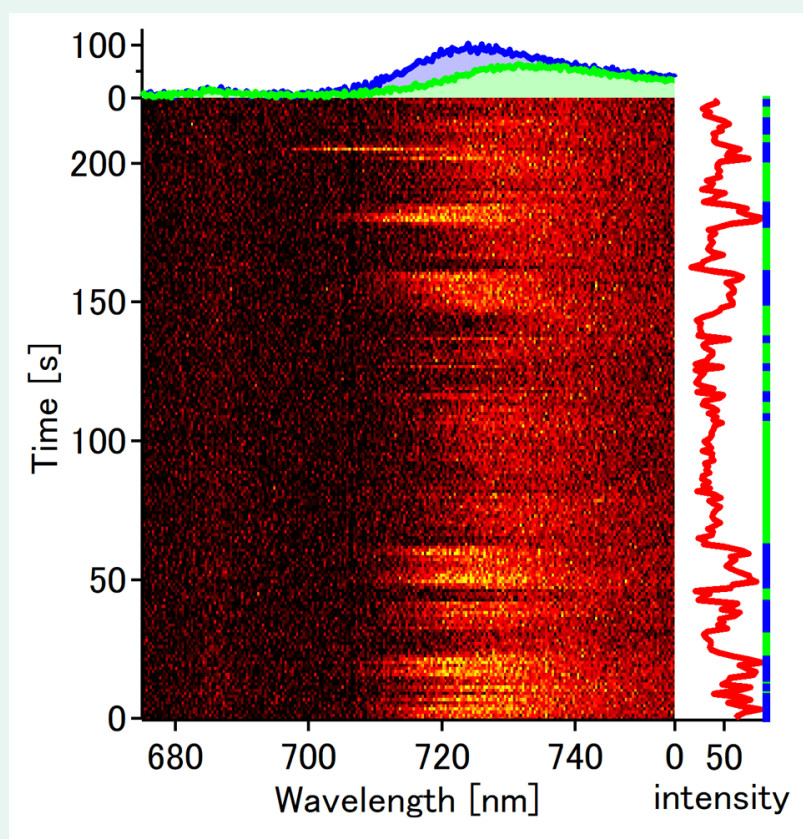

図 2

$100 K$ で測定した単一PSI 蛍光スペクトルの時間変化. 右は強度 変化, 上は強度の高い時間帯 (青) と低い時間帯 (緑) で平均し た蛍光スペクトル.

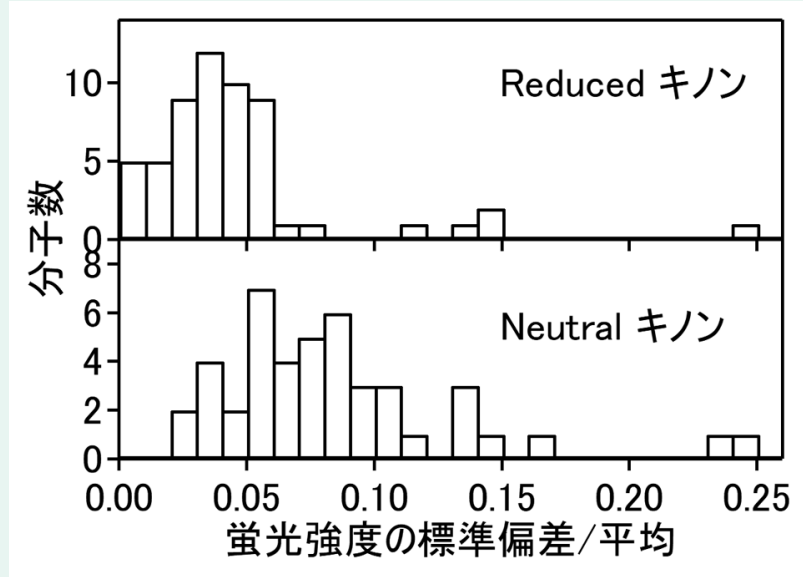

図 3

単一PSI の蛍光明滅の摇らぎ幅のヒストグラム. 蛍光強度の標準 偏差を平均で割った值をヒストグラムにしている. 上は電子受容 体のキノンが還元された状態，下は中性状態.

測定に使ら励起光により繰り返し電荷分離反応が起こ り，平均としてキノンは常に還元状態になる。このよ らに，P700の酸化還元状態を変えてキノンの酸化還 元状態を制御したサンプルを用いた実験により，我々 はキノンの酸化還元状態に依存して蛍光の明滅の幅が 変化することを明らかにした ${ }^{6}$. 図 3 は，蛍光明滅の 相対的な大きさのヒストグラムで，キノンを中性状 態に保つことで蛍光明滅の摇らぎ幅が増大すること を示している。図4にPSI の結晶構造を示すが，マ ジェンタで示したキノン分子は，タンパク質の外縁に 
あるアンテナ色素（緑）集団と中央の P700（赤）の 間を繋ぐ位置に結合しており，その酸化還元状態の変 化がエネルギー移動経路の摇らぎ方を変えていると考 えられる。

さて，単一PSI の蛍光が摇らぐのが観測されたが, 一体何が起こっているのだろらか？図４下に, PSIの アンテナ色素のエネルギー地形を模式的に表した. P700 が酸化されたカチオンの $\mathrm{P} 700^{+}$は，それ自身が 強力な蛍光消光剂として働くことが知られている. 単 一分子の蛍光を検出するための強い励起光照射によ り，測定条件下ではP700 は常時カチオンになってい ると考えられる。そこで，蛍光明滅の機構として考え られるのは，励起エネルギーが蛍光を放出するサイト である red Chl へ多く流れる状態と, 消光サイトであ る $\mathrm{P} 700^{+}$へ多く流れる状態の二状態間を摇らぐ，とい らものである (図4下)。このモデルでは，キノン近 くのクロロフィルのサイトエネルギーの摇らぎが，蛍

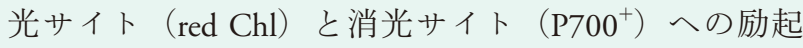
エネルギーの分岐比を摇らして，蛍光明滅が起こる. サイトエネルギーの摇れが，エネルギー移動経路を摇 らしているといらシナリオである.このよらなサイト エネルギーの摇れはより低温の液体 $\mathrm{He}$ 温度でも観測

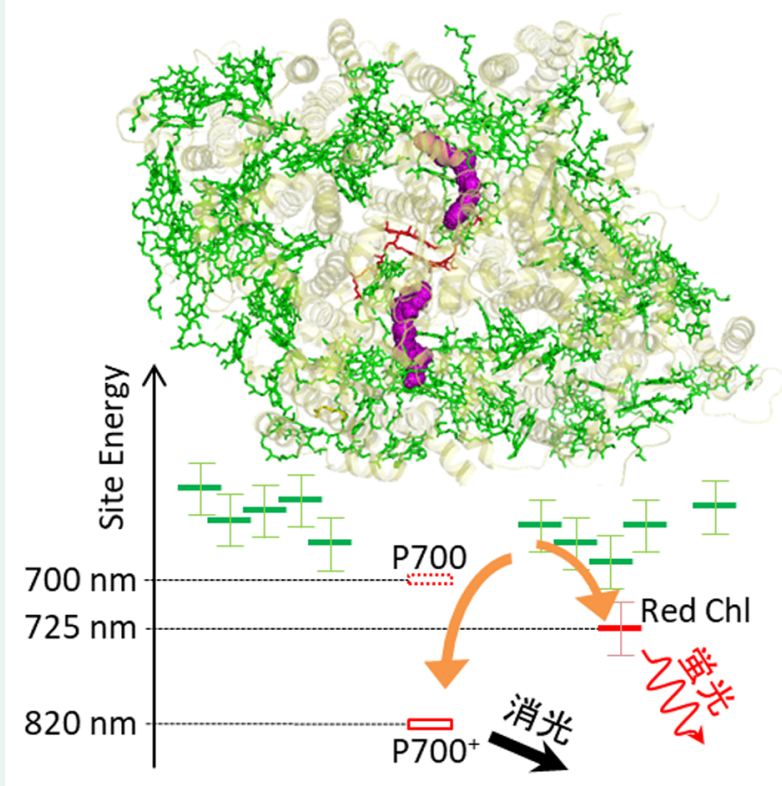

図 4

PSI の結晶構造 (上). アンテナクロロフィルを緑で表し, P700を 赤で, 電子受容体のキノンをマジェンタで示した. PSIのアンテナ 系のサイトエネルギーの模式図による蛍光明滅のモデル (下). 緑 の横線が各アンテナクロロフィルのサイトエネルギー（縦軸）を 表す. red Chl, P700 はそれぞれ赤の横線, 赤の長方形で示す. エラーバーがおよそのサイトエネルギー摇らぎの幅を示す. アン テナクロロフィルのサイトエネルギーの摇らぎにより, red Chl と $\mathrm{P}^{2} 00^{+}$へ流れる励起エネルギーの分岐比が変化し, 蛍光が明滅する.
されており 2)，色素結合タンパク質の微小なコンフォ メーション変化が引き起こす普遍的な現象である.

\section{3.|サイトエネルギー摇らぎの役割}

サイトエネルギーの摇らぎは，機能に積極的な役割 を持つのだろらか？興味深いことに，剛直な構造を持 つと考えられる好熱性シアノバクテリアから精製した 単一PSI では，蛍光スペクトルの摇れはほとんど観測 されなかった（未発表データ）。このことは，タンパ ク質の設計次第でサイトエネルギーの摇らぎをより抑 えた構造にする余地があることを意味する。筆者は, 光合成タンパク質はその生物の生育至適温度で，ある 程度のサイトエネルギーの摇らぎが実現されるよらに 設計されているのではないかと考えている.

サイトエネルギーの摇らぎの意義については，筆者 は以下のように考えている，精密にサイトエネルギー を調節し，その摇らぎも抑えて完璧な漏斗状エネル ギー地形を実現することで，エネルギー捕集の高効率 化は図れる。しかし，光合成系はそのような設計思想 ではなく，むしろエネルギ一地形はある程度いいかげ んにしておいて，サイトエネルギーの摇れを利用して そこそこ速く確実に反応中心へ到達できるよらに設計 されているのではないか? 前者では，エネルギー移動 は最短距離で進行する。この場合，エネルギーの低い アンテナは励起される頻度が高くなり，光による損傷 を受ける確率も高くなる。漏斗の底に位置する低エネ ルギー色素が損傷すれば，光捕集効率も大きく損なわ れることになる，一方後者では，多くの色素分子をま んべんなく経めぐりその後で反応中心へと到達する. 特定のアンテナ色素が損傷を受けやすいということに もならず，またある一つの色素が損傷してもその色素 を回避する経路が多数存在することからエネルギ一捕 集効率が大きく損なわれることもない. 図 1 に示し た PSII のサイトエネルギー地形が漏斗状となってい ないことも，上のような見方の妥当性を示していそう た。.

\section{謝 辞}

精製 PSI は，共同研究者の名古屋大学野口巧教授グ ループから提供されました。杜婷氏，Sankar Jana 博士 の両共同研究者は, 実験, 解析に関して貢献しまし た．近藤徹博士は，原稿を読んで適確な指摘をしてい ただきました。これらの方々に感謝いたします。

文 献

1) Shibata, Y. et al. (2013) J. Am. Chem. Soc. 135, 6903-6914. DOI: 
$10.1021 / \mathrm{ja} 312586 \mathrm{p}$.

2) Brecht, M. et al. (2008) J. Am. Chem. Soc. 130, 17487-17493. DOI: $10.1021 /$ ja806216p.

3） Kruger, T. P. J. et al. (2011) Proc. Narl. Acad. Sci. USA 108, 1351613521. DOI: 10.1073/pnas.1105411108.

4) Kondo, T. et al. (2017) Nat. Chem. 9, 772-778. DOI: 10.1038/ nchem. 2818.

5) Shibata, Y. et al. (2014) Biochim. Biophys. Acta 1837, 880-887. DOI: 10.1016/j.bbabio.2014.03.006.

6) Jana, S. et al. (2020) Biochim. Biophys. Acta 1860, 30-40. DOI: 10.1016/j.bbabio.2018.11.002.

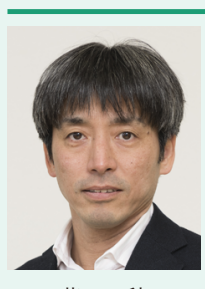

柴田 穣

柴田 穣（しばた ゆたか）

東北大学大学院理学研究科准教授

1997 年大阪大学博士課程修了, 同年レーザー技 術総合研究所, 2001 年名古屋大学大学院理学研 究科助教, 2011 年より現職.

研究内容: 単一分子分光, 細胞内光合成機能解析

連絡先: $7980-8578$ 宮城県仙台市青葉区荒巻字

青葉 6-3

E-mail: shibata@m.tohoku.ac.jp

URL: http://sub.web.tohoku.ac.jp/orgphys/index.htm 